\title{
Otizm Spektrum Bozukluğu Olan Çocuklara Masa Silme Becerisinin Öğretiminde Video Model Olma Uygulamasının Etkililiği ${ }^{1}$
}

\author{
Mehmet YAVUZ \\ Dr. Öğr. Üyesi, Trakya Üniversitesi, \\ Eğitim Fakültesi, Özel Eğitim Bölümü \\ mehmetyavuz@trakya.edu.tr. \\ Orcid ID: https://orcid.org/ 0000-0003-0762-1611
}

\begin{abstract}
Öz
$\mathrm{Bu}$ araştırmada otizm spektrum bozukluğu (OSB) olan çocuklara masa silme becerisinin öğretiminde videoyla model olma uygulamasının etkililiği, kalıcılığ 1 , bireyler arası genelleme ve sosyal geçerliliği araştırılmıştır. Araştırmaya OSB tanısı almıș 3 erkek katılmıștır. Araștırma bir özel özel eğitim kurumunun mutfağında gerçekleştirilmiştir. Araştırmada tek-denekli araştırma modellerinden yoklama evreli denekler arası çoklu yoklama modeli kullanılmıştır. Araştırma sonucunda 3 denekte hedef davranışı kazanmıştır. Deneklerin kazandıkları davranışları başka bireylere de genelleyebildikleri ve kazandıkları davranışları 2, 4 ve 6 . hafta sonra da sürdürebildikleri görülmüştür. Deneklerin öğretmenleri ise hedef davranış ve video model uygulaması hakkında olumlu görüş bildirmişlerdir.
\end{abstract}

Anahtar Kelimeler: Videoyla model olma, Otizm spektrum bozukluğu, günlük yaşam becerileri

\section{The Effectiveness of Video Modeling in Teaching the Skill of Wiping a Table to Children with Autism Spectrum Disorder}

\begin{abstract}
In this study, the effectiveness, permanence, interpersonal generalization and social validity of the Video Modeling Practice in teaching "table cleaning skill" to children with Autism Spectrum Disorder (ASD) were investigated. Three

\footnotetext{
${ }^{1}$ Makale Geliş/Kabul Tarihi: 08.10.2019 / 18.04.2021

Künye Bilgisi: Yavuz, M. (2021). Otizm spektrum bozukluğu olan çocuklara masa silme becerisinin öğretiminde video model olma uygulamasının etkililiği. Kahramanmaraş Sütçü İmam Üniversitesi Sosyal Bilimler Dergisi, 18(1), 246-261. DOI: 10.33437/ksusbd.630995
} 
males who were diagnosed with ASD participated in the study. The study was conducted in the kitchen of a private education institution. Multiple probe design with probe conditions across subjects, which is one of the single-subject research models, was used in the study. As a result of the study, all three subjects acquired the target behavior. It was observed that the subjects were able to generalize these behaviors to other individuals, and to maintain the behaviors after 2, 4 and 6 weeks. The teachers of the participants stated their positive opinions about the target behavior and Video Model Application.

Keywords: Video modeling, Autism spectrum disorder, daily life skills

\section{GİRIŞ}

Otizm spektrum bozukluğu (OSB), "yaşamın ilk yıllarında ortaya çıkan, bireyin günlük yaşama katılımını etkileyen, sınırlı ve yineleyici ilgi, davranış, etkinlikler ve sosyal etkileşim/iletişi̇m eksiklikleri şeklinde kendini gösteren bir nöro-gelişimsel bozukluk" olarak tanımlanmaktadır (Diagnostic and Statistical Manual of Mental Disorders-5 [DSM-5], 2013). OSB'li bireyler gelişim alanlarında gerilikler göstermektedirler. Bu sebeplerden dolayı da öğrenme sorunları yaşamaktadırlar (Kırcaali-İftar, 2012). OSB'li bireylerin öğrenme sorunu yaşadığı en önemli alanlardan biride ve günlük yaşam becerileridir (Jasmin ve diğ., 2009).

Günlük yaşam becerileri Varol'a (2011) göre bireyin ev içinde ve dışında bağımsız olarak yaşamı sürdürebilmesi, bireysel bakım ve görünüşünü koruyabilmesi için gerekli olan bütün becerileri içermektedir (Varol, 2011: 119). Amini, vd.’e (2013) (2013: 742) göre günlük yaşam becerileri normal gelişim gösteren veya engelli bireylerin sosyal hayatta kullanacakları becerilerdir (Amini, vd. 2013: 742). Günlük yaşam becerileri temel günlük yaşam becerileri ve yardımc1 günlük yaşam becerileri olarak ikiye ayrılmaktadır. Temel günlük yaşam becerileri; beslenme, hazırlanma, yıkanma, idrar tutma, tuvalet kullanma, yürüme, giyinme gibi becerilerdir. Yardımcı günlük yaşam becerileri ise; telefon kullanma, yiyecek hazırlama, ev temizleme, çamaşır yıkama, alışveriş yapma, parayı idare etme becerilerinden oluşmaktadır. Bal, vd. (2015) göre OSB'li bireyler bilişsel becerilerinden daha fazla günlük yaşam becerilerinde sorunlar yaşamaktadırlar. $\mathrm{Bu}$ sebeplerden dolayı OSB'li bireylerin için günlük yaşam becerilerini kazanması daha büyük önem arz etmektedir (Bal, vd. 2015: 10).

Günlük yaşam becerileri akademik beceriler kadar önemlidir (Tuncer, 2003) Günlük yaşam becerileri bireyin hem çocuklukta hem de yetişkinlikte bağımsız olarak hareket edebilmesi için gereklidir. Farklı bir ifade ile günlük yaşam becerileri bireyin bağımsız bir birey olması için gereklidir. Günlük yaşam becerilerini öğrenmesi bireyin bağımsız olmasını sağlamasının yanında aileler içinde ek zaman ve enerji tasarrufu sağlayacak ve ailelerin üzerindeki yükü 
azaltacaktır (Shipley-Benamou, Lutzker ve Taubman, 2002: 166). Bunlara ek olarak günlük yaşam becerileri okula başlamak içinde gerekli becerilerdendir (Jasmin vd., 2009). Ergenekon'a (2012) göre yetersizliği olan bireylere verilen eğitimin amacı bu bireyleri üretken, kendilerine yeterli bir birey olmaları ve kimseye bağlı olmadan hayatlarını idame ettirmeleridir (Ergenekon, 2012: 2739). $\mathrm{Bu}$ sebeple yetersizliği olan bireylere yaşamlarını kolaylaştıracak günlük yaşam becerilerinin öğretilmesi gerekmektedir.

Alanyazında OSB'li bireylere etkili öğretim vermek için çeşitli öğretim uygulamaları bulunmaktadır. Ancak özellikle 2000'li yıllardan itibaren, OSB'li bireylere öğretim sunmak için bilimsel dayanaklı uygulamaların kullanılmasına dikkat edilmektedir (Kurcaali-İftar, 2012: 24). Bunun yanında bu bireylerin eğitiminde, etkili olduğu bilinen resimlerin ve videoların kullanılması da önerilmektedir. Bu sebeplerden dolayı OSB'li çocuklara eğitim verilirken teknolojiye dayalı video temelli uygulamalarının kullanılmasını zorunluluk haline gelmiştir (Tekin-İftar ve Değirmenci, 2012: 304). Videoyla model olma bilimsel dayanaklı (Nikopoulos ve Keenan, 2003), sosyal öğrenme kuramına dayanan ve yeni davranışların öğrenilmesi ya da olan davranışın değiştirilmesi için kullanılan etkili bir uygulamadır (Bidwell ve Rehfeldt, 2004; Delano, 2007; Nikopoulos ve Keenan, 2007). Videoyla model olma Mechling'e (2005) göre üç farklı şekilde uygulanmaktadır. Bunlar; a) videoyla geribildirim (video feedback), b) videoyla ipucu (video prompting), c) videoyla model olma (video modeling) (Mechling, 2005: 26).

Video geribildirim: Video geribildirim öğrenci hedef davranışı sergilerken videoya kaydedilir. Daha sonra kaydedilen video öğrenci ve öğretici tarafından izlenir. Videoyu izlerken öğrenciye yaptığ hatalar ve doğru davranışlar hakkında geri dönütler sunulur (Dowrick, 1999: 25; Embregts, 2002). Öğrenci kendisine sunulan bu geri dönütlere göre gelecekte performansını yeniden düzenler (Embregts, 2002).

Videoyla model olma: Videoyla model olma hedef beceri bir model tarafından sergilenirken kamera ile kaydedilir. Daha sonra video uygun şekilde montajlanıp öğrencinin izleyeceği düzeye getirilir ( Nikopoulos ve Keenan, 2003: 88). Daha sonra video kaydı öğretim verilecek bireye izletilir ve ardından bireyden izlediği davranışı sergilemesini içeren bir uygulamadır (Bellini ve Akullian, 2007: 265; Delano, 2007; Nikopoulos ve Keenan, 2003: 88). Videoyla model olma uygulamasında bireye ya yeni bir beceri veya hatalı ya da eksik sergilediği becerinin doğru olarak sergilemesi öğretilmektedir (Nikopoulos ve Keenan, 2003: 88).

Video ipucu: Video ipucu bu video uygulaması videoyla model olmanın farklı bir şeklidir. Videoyla model olma uygulamasında hedef beceri bir bütün 
olarak öğrenciye izlettirilerek daha sonra öğrenciden beceriyi sergilemesi istenir. Video ipucunda ise video öğrencinin bireysel özelliğine bağl1 olarak video küçük basamaklara bölünür. Öğrenciye ilk basamaktan başlayarak her defasında sadece bir basamağı izlemesi ve daha sonra sergilemesi istenir. Birey bu basamakta ustalaştıkça diğer basamağa geçilir (Shipley-Benamou, Lutzker ve Taubman, 2002).

Alan yazınına baktığımız OSB'li bireylere günlük yaşam becerilerinin öğretiminde videoyla model olma uygulamasının kullanıldığı çeşitli araştırmalar bulunmaktadır. Aldi Crigler, Kates-McElrath, Long, Smith, Rehak ve Wilkinson (2016) ayna temizleme, lavaboyu temizleme, masa hazırlama, kot pantolonu katlama ve tortellini makarna yapma, Ayres, Maguire ve McClimon (2009) masa hazırlama, çorba yapma ve sandviç hazırlama, Kuder (2015) tabak yıkama, dişlerini firçalama ve sandviç yapma, Bozkurt (2011) çorba pişirme oyunu ve ilk yardım oyunu, Ergenekon Tekin-İftar, Kapan ve Akmanoğlu, (2014) masa hazırlama, kazak katlama, portakal suyu sıkma, tost yapma, araba sürme ve patates kafa inşa etme oyunu, Genç (2010) kakaolu süt hazırlama, sandviç hazırlama, mısır patlatma, sıcak içecek hazırlama, toz içecek hazırlama, çikolatalı ekmek hazırlama ve kahvaltı gevreği hazırlama, Shipley-Benamou vd. (2002) meyve suyu hazırlama, mektup atma, masa hazırlama ve evcil hayvan bakımı, Yavuz (2016) kaşarlı tost yapma ve poşet çay hazırlama ve Yavuz, (2019) elbise katlama becerileri çalışıldığı görülmektedir. $\mathrm{Bu}$ araştırmalara bakıldığında OSB'li bireyle yapılacak daha fazla araştırmalara gereksinim duyulmaktadır. Bunun yanında videoyla model olma uygulamasının OSB'li bireylerde farlı günlük yaşam becerilerinin öğretiminde etkililiğine dair daha fazla kanıt sunmaktır. $\mathrm{Bu}$ sebeple bu araştırmanın amacı OSB'li bireylere günlük yaşam becerilerinden masa silme becerisinin öğretiminde videoyla model olma uygulamasının etkililiğini incelemektir. Bu amaçla aşağıda yer alan sorulara yanıt aranmıştır:

1. Videoyla model olma uygulaması araştırmaya katılan OSB'li bireylere masa silme becerisinin öğretiminde etkili midir?

2. Videoyla model olma uygulaması araştırmaya katılan OSB'li bireylere masa silme becerisinin öğretiminde gösterdikleri performanslarını iki, dört, altı hafta sonra sürdürmekte midirler?

3. Videoyla model olma uygulaması araştırmaya katılan OSB'li bireylere masa silme becerisinin öğretiminde kazandırılan beceriyi kişiler arası genelleyebilmekte midirler?

4. $\mathrm{Bu}$ araştırmaya deneklerin öğretmenlerinin belirlenen masa silme becerisine ve videoyla model olma uygulamasına yönelik görüşleri (sosyal geçerlik) nelerdir? 


\section{Yöntem}

\section{Araştırma modeli}

Araştırmada tek-denekli araştırma modellerinden yoklama evreli denekler arası çoklu yoklama modeli kullanılmıştır. Araştırmada öğretime başlamadan tüm denklerde eş zamanlı olarak başlama düzeyi ve genelleme verisi toplanmıştır. İlk denekte kararlı veri elde edildikten sonra ilk denekte öğretim oturumlarına geçilmiştir. İlk denek beceriyi ölçütü karşılayacak düzeyde ustalaştıktan sonra tüm deneklerde yeniden eşzamanlı olarak yoklama evresi gerçekleştirilmiştir. Daha sonra ikinci denekte kararlı veri elde edildikten sonra ikinci denekte öğretim oturumlarına geçilmiştir. İkinci denek beceriyi ölçütü karşılayacak düzeyde ustalaştıktan tüm deneklerde yeniden eşzamanlı olarak yoklama evresi uygulanmıştır. Yoklama evresinden sonra üçüncü denekte de kararlı veri elde edildikten sonra üçüncü denekte öğretim oturumlarına başlanmıştır. Üçüncü denekte ölçütü karşılayan kararlı veri elde ettikten sonra tüm deneklerde eşzamanlı olarak son olarak yoklama evresi uygulanmıştır. Araştırmanın deneysel kontrolü öğretim yapılan deneğin performansının öğretim öncesine göre artış görülmesiyle, öğretim gerçekleştirilmeyen deneklerdeki performanslarının benzer şekilde kalması ve daha sonra diğer deneklerde öğretim gerçekleştikten sonra performanslarında artış olmasıyla kurulmuştur (Tekin ve Kırcaali-İftar, 2001).

\section{Bağımlı Değişken- Bağımsız Değişken}

$\mathrm{Bu}$ araştırmanın bağımlı değişkenini masa silme becerisi oluşturmaktadır. Araştırmanın bağımsız değişkeni ise video modelle öğretim yöntemidir.

\section{Katılımcilar}

Hakan: 9 yaşında ve OSB tanısı bulunmaktadır. Hakan hem devlet kurumuna devam etmekte hem de özel özel eğitim rehabilitasyon merkezine devam etmektedir. İki kelimelik yönergeleri yerine getirmekte, bir etkinlikle 7-8 dk. ilgilenebilmekte, bağımsız olarak tuvaletini yapabilmekte, bağımsız olarak giyinip-soyunabilmektedir. Hakan basit taklit becerilerini yerine getirebilmekte ve heceleyerek okuma becerisine sahiptir. Kendisine okunan bir metinde metinle ilgili soruları sözel olarak cevaplayabilmektedir. İlkokul 2. sınıf düzeyinde matematik becerilerine sahiptir.

Kemal: 9 yaşında ve OSB tanısı bulunmaktadır. Hakan hem devlet kurumuna devam etmekte hem de özel özel eğitim rehabilitasyon merkezine devam etmektedir. Üç kelimelik ardışık yönergeleri yerine getirebilmektedir. Öz-bakım becerilerini bağımsız olarak yerine getirebilmektedir. Bir etkinlikle 5 dakika 
ilgilenebilmektedir. İlkokul 2. sınıf düzeyinde matematik becerilerine ve okumayazma becerilerine sahiptir.

Ozan: 10 yasında ve OSB tanısı bulunmaktadır. Üç kelimelik ardışık yönergeleri yerine getirir. İlkokul 3. Sinıf dizeyinde matematik becerilerine sahiptir. Bir etkinlikle 6 dakika ilgilenebilmektedir. Okuma-yazma becerilerine ve motor taklit becerilerine sahiptir.

\section{Uygulamacı}

Araştırmacı zihin engellilerin eğitim alanında lisans, yüksek lisans ve doktora derecesine sahiptir. Halen Trakya Üniversitesi Özel Eğitim Bölümünde Doktor Öğretim Üyesi olarak görev yapmaktadır.

\section{Akran Model}

Videoda model olarak bir erkek akran kullanılmıştır. Akran model deneklerin tanımadığı biridir. Modele öncelikle beceri anlatılmıştır. Çalışmanın yapılacağı ortamda birkaç prova yapıldıktan sonra HD kamera ile kayıt yapılmıştır.

Gözlemci: Bağımlı ve bağımsız değişkenle ilgili güvenirlik verileri, uygulamacı ve özel eğitim alanında lisans, yüksek lisans ve doktora derecelerine sahip iki alan uzmanı tarafindan toplanmıştır. İki gözlemcide video modelle çalışmaları bulunmaktadır. Öncelikle gözlemcilere nasıl puanlama yapacakları ve puanlama ölçütleri hakkında bilgi sunulmuştur. Daha sonra gözlemcilerden belirtilen ölçütleri göre video kayıtlarını izlemeleri ve öğrenci davranışlarını puanlamaları istenmiştir.

\section{Ortam ve Araç-Gereçler}

Araştırma deneklerin devam ettiği özel kurumunda mutfağında gerçekleştirilmiştir. Araştırmanın başlama düzeyi, öğretim, kalıcılık ve genelleme oturumları aynı ortamda uygulanmıştır. Mutfakta 1 yemek masası 4 sandalye, bir buzdolabı, çeşitli mutfak malzemesi, mutfak tezgâhı, çöp kutusu, temizlik bezi ve yüzey temizleme deterjanı bulunmaktadır.

Araştırmada hedef beceri için hazırlanmış video görüntüleri, 15.inc büyüklügünde diz üstü bilgisayarı, bilgisayar kablosu, Hd kayıt yapan kamera, tripod, veri toplama formları (yoklama, izleme ve genelleme için) ve kalem. 
Tablo 1. Masa Silme Beceri Analizi

\begin{tabular}{ll}
\hline 1. & Silme bezini tezgâhın üzerinde alır. \\
2. & Musluğu açar. \\
3. & Silme bezi muslukta ıslatır. \\
4. & Musluğu kapatır. \\
5. & Islak silme bezini sıkar. \\
6. & Masanın yanına gelir. \\
7. & Islak silme bezi masanın yüzeyinde dairesel olarak hareket ettirerek \\
& kirli yüzeyi temizler. \\
8. & Islak silme bezini tezgâhın üzerine bırakır. \\
9. & Kuru silme bezini tezgâhın üzerinde alır. \\
10. & Kuru silme bezini masanın yüzeyinde dairesel olarak hareket ettirerek \\
& 1slak yüzeyi kurular. \\
11. & Kuru silme bezini tezgâhın üzerine bırakır. \\
\hline
\end{tabular}

\section{Olası Denek Tepkileri}

Araştırma sürecinde deneklerden öğretim, yoklama, genelleme ve izleme oturumlarında üç tür tepki sergilemesi beklenmektedir. Bunlar doğru tepki, yanlış tepki ve tepkide bulunmama. Doğru tepki, bireye beceri yönergesi sunulduktan sonra hedef davranış 5 saniye içinde başlatması ve belirlenen sürede bitirmesidir. $\mathrm{Bu}$ tepkiyi beceri analizindeki sıraya göre her beceri basamağ 1 için uygulamasıdır. Doğru tepkiler sözel ve sosyal pekiştireçlerle pekiştirilmiştir. Yanlış tepki, deneğe yönerge sunulduktan sonra 5 saniye içinde tepkide bulunduktan sonra beceri yanlış sergilemesi ya da farklı bir beceri basamağını sergilemesi veya belirlenen sürede bitirmemesi olarak belirlenmiştir. Tepkide bulunmama: deneğe beceri yönergesi sunulduktan sonra hiçbir tepkide bulunmaması olarak belirlenmiştir.

\section{Deney Süreci}

Deney sürecinde her bir denek için başlama düzeyi, öğretim, yoklama ve izleme oturumlarına yer verilmiştir.

\section{Yoklama Oturumları}

Yoklama oturumları, toplu yoklama oturumları ve günlük yoklama oturumları şeklinde gerçekleştirilmiş̧ir. Toplu yoklama oturumları başlama düzeyinde ve her denekte öğretim bittikten sonra tüm deneklerde eşzamanlı olarak gerçekleştirilmiştir. Günlük yoklama oturumları ise deneklerde birinci öğretim 
oturumu hariç öğretim oturumlarının başında ve sadece öğretim uygulanan denek için uygulanmıştır.

Her 3 denekte öğretime başlamadan önce başlama düzeyi yoklama oturumları üç gün bir yoklama oturumu ve her oturumda bir deneme uygulanmıştır. Başlama düzeyi yoklama oturumları her denk için kararlı veri elde edilinceye kadar üç oturum üst üste gerçekleştirilmiştir. Başlama düzeyi yoklama oturumlarında tek fırsat yöntemi kullanılmıştır. Başlama düzeyi yoklama oturumlarında denekler uygulama için gerekli materyallerin bulunduğu mutfağa alınmıştır. Öğrenciye uygulamanın yapılacağı materyaller tanıtılmıştır. Öncelikle çocuğun dikkati çalışmaya çekilmiştir. Öğrenciye "Kemal masa silmeye hazır mısın? Şeklinde soru yöneltilmiştir. Öğrenciden hazır olduğuna belirten söz, jest, mimik vb. bir tepki alındığında öğrenciye "masayı sil" yönergesi sunulmuştur. Öğrenciye yönerge sunulduktan sonra beceri basamağının ilk basamağını başlatması için 5 saniye süre verilmiştir. Öğrenci ilk basamağı doğru olarak sergilediğinde veri toplama formunda ilk basamağa artı (+) işareti atılmış ve bir sonraki basamağa geçilmiştir. Öğrenci birinci basamağ 5 saniye başlatmaz veya doğru olarak sergileyemezse veri toplama formunda bu basama eksi (-) işareti atılmış, ve uygulama sonlandırılmıştır.

\section{Öğretim Oturumları}

Öğretim oturumu, günde bir öğretim oturumu ve her oturumda bir deneme gerçekleştirilmiştir. Öğretim oturumlarında denek uygulamanın yapılacağı mutfağa alınmıştır. Uygulama ortamına yakın bir yere diz üstü bilgisayar yerleştirilmiştir. Öğrenci bilgisayarın olduğu masanın yanındaki sandalyeye oturtulmuştur. Öğrenciye öğrenilecek davranışın önemi hakkında bilgi verilmiştir. Öğrenciye "şimdi seninle bir video izleyeceğiz. Daha sonra sen videoda izlediğinin aynısını yapacaksın" denilmiştir. "Şayet videoyu izler daha sonra izlediğinin aynısın yaparsan sana ... vereceğim" denilmiştir. Daha sonra bilgisayardan video açılmış öğrenciye izlettirilmiştir. Öğrenci videoyu izleme davranışı "aferin çok güzel videoyu izliyorsun" sözel olarak pekiştirilmiştir. Öğrenci videoyu izlemediği zaman "videoyu izle" şeklinde uyarılmıştır.

Video izlendikten sonra deneğe "masayı sil" yönergesi sunulmuştur. Öğrenciye beceriyi başlatması için 5 saniye verilmiş̧ir. Deneğin başarıyla gerçekleştirdiği davranışlar sözel olarak pekiş̧irilmiş̧ir. Deneğin yanlış yaptı̆̆ basamakta veya hiç bir şey yapmadan durduğu basamakta deneye "dur şimdi videoyu tekrar izleyelim" denilmiştir. Video baştan izletilmiş kullanılan materyaller eski yerine konulmuştur. Videoyu izleme prosedürü baştan uygulanmıştır. Deneğe tekrar video izletildikten sonra deneğe "masayı sil" yönergesi tekrar sunulmuştur. Deneğin başarıyla gerçekleştirdiği davranışlar 
sözel olarak tekrar pekiştirilmiştir. Deneğin yanlış yaptığı basamakta veya hiç bir şey yapmadan durduğu basamakta oturum sonlandırılmıştır.

\section{İzleme ve genelleme Oturumları}

İzleme oturumları öğretim sona erdikten sonra 2,4 ve 6 . haftalarda gerçekleştirilmiştir. Genelleme oturumları bireylerarası şeklinde gerçekleştirilmiştir. Genelleme oturumları başlama düzeyinde ve uygulama sona erdikten sonra toplu yoklama oturumları şeklinde gerçekleştirilmiştir.

\section{Güvenirlik}

Araştırmada gözlemciler arası güvenirlik ve uygulama güvenirliliği verisi toplanmıştır. Araştırmada başlama, günlük yoklama, izleme ve genelleme oturumlarının \%30'undan yansız atama yoluyla gözlemciler aras1 güvenirlik verisi toplanmıştır. Gözlemciler arası güvenirlik verilerinin analizi için: "Görüş birliği/görüş birliği+görüş ayrılığ $\mathrm{X}$ 100" formülü kullanılmıştır. Uygulama güvenirliği için; "Gözlenen uygulamacı davranışı/planlanan uygulamacı davranışı X 100” formülü kullanılmıştır (Ayres ve Gast, 2010).

Gözlemciler arası güvenirlik verisi yüzdesi toplu yoklama oturumlarında, günlük yoklama, izleme ve genelleme oturumlarında Hakan, Kemal ve Ozan için $\% 100$ olarak bulunmuştur. Uygulama güvenirliği verisi için belirlenen beceriler: a) Video hazır mı? b) Çocuğun dikkati sağlandı mı? c) Videoyu izlemesi sağlandı mı? d) Çocuk videoyu izlemediğinde uyarı yapıldı mı? e) videoyu izlediğinde pekiştireç verildi mi? f) araç-gereçler hazır mı? g) Ortamda çocuğun dikkatini dağıtacak uyaranlardan arındırılmış $\mathrm{m} ı$ ? h) Beceri yönergesi uygun olarak verildi mi? 1) Çocuğun tepkilerine uygun tepki verildi mi? Uygulama güvenirliği verisi Hakan için ortalaması \%94,44, Kemal ve Ozan için ise \%100 olarak bulunmuştur.

\section{Bulgular}

$\mathrm{Bu}$ bölümde masa silme becerisine ilişkin etkililik, izleme, genelleme ve sosyal geçerlilik bulgularına yer verilecektir. Etkililik, izleme ve genelleme bulguları grafiğinde yatay eksen oturum sayısını, düşey eksen günlük yoklama oturumlarını, genelleme, öğretim oturumları ve kalıcılık oturumlarındaki doğru tepki yüzdelerini göstermektedir. 


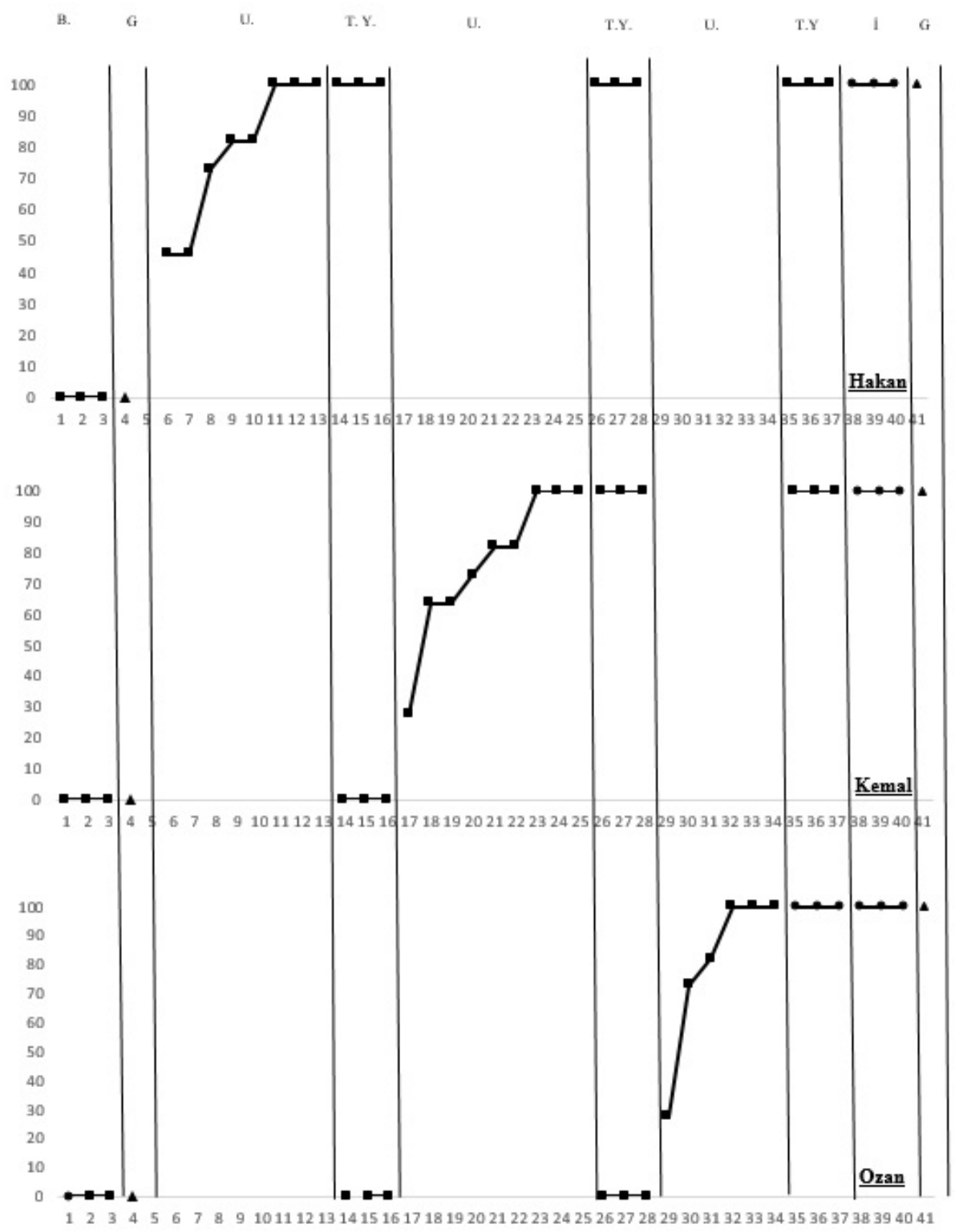

Şekil 1. Videoyla model olma ile masa silme becerisi edinim, kalıc1lık ve genelleme doğru tepki yüzdeleri (B: Başlama, G: Genelleme, U: Uygulama, T.Y: Toplu Yoklama, İ:İzleme)

Şekil 1 incelendiğinde, deneklerden Hakan masa silme becerisini başlama düzeyi performansı \%0'dır. Video modelle öğretime geçildiğinde Hakan 8 oturum sonunda üç oturum ard arda \%100 doğrulukla sergilemiştir. Kemal'in 
masa silme becerisini başlama düzeyi performans $1 \% 0$ 'dır. Kemal Video modelle öğretime geçildiğinde masa silme becerisini 9 oturum sonunda üç oturum ard arda \%100 doğrulukla sergilemiştir. Ozan'la masa silme becerisini başlama düzeyi performansı $\% 0$ 'dır. Video modelle öğretime geçildiğinde Ozan ise silme becerisini 6 oturum sonunda üç oturum ard arda \%100 doğrulukla sergilemiştir. İzleme verilerinde ise Hakan, Kemal ve Ozan'in 2. hafta, 4. hafta ve 6. hafta sonra gerçekleştirilen izleme verilerinde masa silme becerisini \%100 düzeyinde koruduğu görülmüştür. Bireyler arası genelleme verilerinde Hakan, Kemal ve Ozan'ın masa silme becerisinde başlama düzeyinde $\% 0$ olduğu görülmektedir. Öğretim sonunda yapılan genelleme verilerinde ise $\% 100$ olduğu görülmektedir.

\section{Tartışma ve Yorum}

$\mathrm{Bu}$ araştırmada OSB'li bireylerin masa silme becerisinin öğretiminde videoyla model olmanı etkililiği, izleme, genelleme ve ailelerin sosyal geçerlilik hakkındaki görüşleri incelenmiştir. Araştırma sonuçlarına göre videoyla model olma günlük yaşam becerilerinin öğretiminde tüm deneklerde başlama düzeyi ile öğretim sonun verileri arasında belirgin fark olduğu gizlenmektedir. Bu bulgular alan yazınında çeşitli günlük yaşam becerilerinin videoyla model olma ile öğretimi bulgularıyla paralellik göstermektedir (Aldi, vd., 2016; Bozkurt, 2011; Ergenekon vd., 2014; Fabrizio, 2016; Genç, 2010; Kuder, 2015; Yavuz, 2016; Yavuz, 2019). Buna karşın günlük yaşam becerilerinin video model olma ile bazı araştırmalarda bazı deneklerin hedef davranışları kazanamadıkları gözlenmiştir. Mechling ve O'Brien, (2010) yaptıkları araştırmada iki denekte başarılı, bir ise denekte başarısız olduğu gözlenmiş. Ayres, Maguire ve McClimon’da (2009) yaptıkları araştırmada iki denekte başarılı, bir denekte başarısız olduğu gözlenmiş̧ir. $\mathrm{Bu}$ araştırmada sonuçlarına göre videoyla model olmanın etkili olmasının nedeni OSB'li bireylere görsel desteğin sağlanmasıdır. Çünkü OSB'li bireylerin en güçlü yönleri, görsel işleme anlama becerileridir (Grandin, 2005; Spencer, 2002).

$\mathrm{Bu}$ araştırmada izleme verileri 2., 4. ve 6. Haftalarda toplanmıştır. Alanyaznına OSB'li bireyle yapılan günlük yaşam becerilerinin öğretiminde videoyla model olama uygulamalarında baktığımızda çeşit sürelerde izleme verileri toplandığını görmekteyiz. Yavuz (2016) yaptığı araştırmada 15, 30 ve 45 gün sonra edinilen davranışın kalıcılı̆̆ının korunduğu gözlenmiştir. Aldi, vd., (2016) günlük yaşam becerilerinin öğretiminde videoyla modelle uygulamalarında tüm denekler bir ayın sonunda izleme verilerinde davranışları \%100 olarak sergileyemedikleri ancak başlama düzeyinin üzerinde olduğunu gözlemişlerdir. Benzer şekilde Yavuz (2019) yaptığı araştırmada iki denekte 10, 20, 30. gün sonra kalıcılığın korunduğu bir denekte ise, 10. ve 20 gün sonra kalıcılık verisi toplanmış ve deneklerde kalıcılı̆̆ın devam ettiği gözlenmiştir. Buna karşın alanyazınında farklı kalıcılık verileri bulunmaktadır. Shipley- 
Benamou, Lutzker ve Taubman, (2002) OSB'li bireyle yapılan günlük yaşam becerilerinin öğretiminde videoyla model olma uygulamasında denekler iki davranışın kalıcılığını 1 ay sonra sürdüğü ancak bir davranışı ise \%80 oranında sürdürdüğü gözlenmişlerdir. Kuder (2015) yaptığı araştırmada kalıcılığının sınırlı olduğunu ifade etmiştir. Bu verilere bakarak OSB'li bireylere günlük yaşam becerilerinin öğretiminde videoyla model olma uygulamasıyla edinilen davranışların kalıcılığının yüksek olduğu söylenebilir.

Araştırma sonuçlarına göre OSB'li bireylere günlük yaşam becerilerinin ögretiminde videoyla model olma uygulamasının farklı bireylere genellemesinin olduğu görülmüsştür. Alanyazınına baktığımızda OSB'li bireylere günlük yaşam becerilerinin öğretiminde videoyla model olma uygulamasında genelleme çalışmaları yapıldığı görülmektedir. Ergenekon vd., (2014), Mechling ve O’Brien, (2010) ve Shipley-Benamou, Lutzker ve Taubman, (2002) ortamlar arası, Genç (2010) bireyler arası ve Bozkurt, (2011) ortamlar arası, bireyler arası ve materyaller arası genelleme çalışması yaptıkları görülmektedir. Bu araştırma sonuçlarına göre OSB'li bireylere günlük yaşam becerilerinin öğretiminde videoyla model olma uygulamasının bireyler arası genellemesinin yüksek olduğu söylenebilir.

Araştırmanın sosyal geçerlilik verileri deneğin öğretmenlerinden toplanmıştır. Öğretmeneler gerek hedef beceri gerekse video model uygulaması için olumlu görüş bildirmişlerdir. Alanyazınına baktığımızda Ergenekon (2012), Ergenekon vd., (2014) ailelerle Yavuz (2019), Genç (2010) öğretmenlerle, Ayres, Maguire ve McClimon (2009) çocukların kendileriyle ve Francis (2010) okul çalışanlarıyla sosyal geçerlilik verisi toplandığını görmekteyiz. Bunun yanında Shipley-Benamou, Lutzker ve Taubman, (2002) ve Lee, Anderson ve Moore (2014) sosyal geçerlilik verisi tonlamamışlardır. Bu araştırma sosyal geçerlilik verisi toplanması açısından alanyazınına katkı sağlamaktadır.

$\mathrm{Bu}$ araştırmada kullanılan videoda model olarak deneklerle aynı yaş ve cinsiyetten model kullanılmışır. Alanyaznınına baktığımızda videoyla model olma uygulamalarında videolarda model kullanımı çeşitli şekillerde kullanılabilmektedir: Akran model, yetişkin model, kendine model olma, kişisel görüş noktası (point-of-view) ve karışık model kullanılabilir (McCoy ve Hermansen, 2007). Buna karşın akran modelin daha etkili olduğu görülmektedir (Bidwell ve Rehfeldt, 2004). Bu araştırmada da deneklerle aynı yaş grubundan ve aynı cinsiyetten modelin kullanılması denekler üzerinde olumlu etki yarattığ 1 düşünülmektedir.

$\mathrm{Bu}$ araştırmanın belli sınırlılıkları bulunmaktadır. $\mathrm{Bu}$ araştırma OSB'li bireylerle, masa silme becerisi ile farklı materyallerle ve farlı ortamlarda çalış1lmaması ve 2., 4. ve 6 haftada genelleme verisi toplanması ve sadece 
öğrencilerin öğretmenleriyle sosyal geçerlilik verisi toplanması ile sınırlıdır. İleriki araştırmalar farklı yetersizlik gruplarıyla, farklı günlük yaşama becerileri ile gerçekleştirilebilir. Bunun yanında araştırmada videoda akran ve kendi cinsiyetinden model kullanılmıştır. İleriki araştırmalarda farklı cinsiyetten ve farklı yaş gruplarından modeller kullanılarak gerçekleştirilebilir. Videoyla model olma uygulaması ailelere öğretilebilir. Şuan görev yapmakta olan özel eğitim öğretmenlerine ve sınıf öğretmenlerine video model olma uygulamasını nasıl hazırlanıp uygulanacağı konusunda seminerler verilebilir.

$\mathrm{Bu}$ araştırma sonuçlarına göre video modelle öğretim OSB'li çocuklara günlük yaşam becerilerinin öğretiminde etkili ve öğretim bittikten sonra davranışın kalıcılığını sağlayan bir yöntemdir. Bunun yanında video modelle öğretim OSB'li çocuklara günlük yaşam becerilerinin öğretiminde farklı bireylere genelleyebilmesi açısında da uygun bir yöntemdir. Araştırmanın sosyal geçerlilik verilerinde ise deneklerin öğretmenleri hedef davranış ve video model uygulaması hakkında olumlu görüş bildirmişlerdir.

\section{KAYNAKÇA}

Aldi, C., Crigler, A., Kates-McElrath, K., Long, B., Smith, H., Rehak, K., and Wilkinson, L. (2016). Examining the effects of video modeling and prompts to teach activities of daily living skills. Behav Analysis Practice, https://doi.org/10.1007/s40617-016-0127-y.

Amini, R., Sahaf, R., Kaldi, A., Haghani, H., Davatgaran, K., Masoumi, M., and Rassafiani, M. (2013). Activities of daily living independence in Iranian blind war survivors: A cross sectional study, 2008. Geriatrics \& Gerontology International, 13(3), 741-750. https://doi.org/10.1111/j.1447-0594.2012.00954.x

APA (American Psychiatric Association) (2014). DSM-5 tanı ölçütleri başvuru el kitabl. (E. Köroğlu, Çev). Hekimler Yayıncılık.

Ayres, K. M., Maguire, A. and McClimon, D. (2009). Acquisition and generalization of chained tasks taught with computer based video instruction to children with autism. Education and Training in Developmental Disabilities, 44(4), 493-508

Ayres, K. and Gast, L. D. (2010). Dependet measures and measurement procedures. Gast. D. L. (Ed.) Single subject research methodology in behavioral sciences (ss. 129-165) Routledge. 
Bal, V. H., Kim, S., Cheong, D. and Lord, C. (2015). Daily living skills in individuals with autism spectrum disorder from 2 to 21years of age. Autism, 19(7) 774-784. https://doi: 10.1177/1362361315575840.

Bellini, S., and Akullian, J. (2007). A meta-analysis of video modeling and video self-modeling interventions for children and adolescents with autism spectrum disorders. Exceptional Children, 73, 264-287. https://doi.org/10.1177/001440290707300301

Bidwell, M. A. and Rehfeldt, R. A. (2004). Using video modeling to teach a domestic skill with an embedded social skill to adults with severe mental retardation. Behavioral Interventions, 19(4), 263-274. https://doi: 10.1002/bin.165

Bozkurt S. S. (2011). Otizmli çocuklara rol oyun becerilerinin öğretiminde akran ve yetişkin modelin kullanıld $\breve{g} \mathrm{l}$ video modelin etkililiğ $i$ ve verimlilĭgi. [Yayımlanmamış yüksek lisans tezi]. Anadolu Üniversitesi.

Delano, M. E. (2007). Video modeling interventions for individuals with autism. Remedial and Special Education, 28, 33-42. https://doi.org/10.1177/07419325070280010401

Dowrick, P. W. (1999). A review of self modeling and related interventions. Applied \& Preventative Psychology, 8, 23-39. https://doi.org/10.1016/S0962-1849(99)80009-2

Embregts, P. J. C. M. (2002). Effects of video feedback on social behavior of young people with mild intellectual disability and staff responses. International Journal of Disability, Development, and Education, 49, 105-116. https://doi.org/10.1080/10349120120115361

Ergenekon, Y. (2012). Otizmli çocuklara videoyla model olma kullanılarak ev kazalarında basit ilkyardım becerilerinin öğretimi. Kuram ve Uygulamada Ĕ̈itim Bilimleri Dergisi, 12 (4) 2739-2766.

Ergenekon, Y., Tekin-İftar, E., Kapan, A. ve Akmanoğlu, N. (2014). Comparison of video and live modeling in teaching response chains to children with autism. Education and Training in Autism and Developmental Disabilities, 49 (2), 200-213.

Fabrizio, L. J. (2016). The effects of video modeling on the acquisition of daily living skills in students with autism. [Unpublished doctoral dissertation]. Caldwell University Program of Special Education Caldwell University. ABD. 
Francis, K. (2010). Using video modeling to elicit a functional skill for a student with ASD. [Unpublished Master's dissertation]. Department of Special Education, Kansas.

Genç, D. (2010). Otistik özellikler gösteren çocuklara eşzamanlı ipucuyla ögretim ile eşzamanl ipucuyla öğretim ve video modelle öğretimin birlikte sunulmasının etkilerinin karşılaşsırılması, [Yayımlanmamış yüksek lisans tezi]. Anadolu Üniversitesi.

Grandin, T. (2005). Resimlerle düşünme - otizmin içerden anlatımı (otizmin içerden anlatımı). (M. C. İftar. Çev.) Doğan Yayıncılık

Jasmin, E., Couture, M., McKinley, P., Reid, G., Fombonne, E. and Erika Gisel, E. (2009). Sensori-motor and daily living skills of preschool children with autism spectrum disorders. Journal of Autism and Developmental Disorders, 39,231-241. https://doi.10.1007/s10803-008-0617-z

Kırcaali-İftar, G. (2007). Otizm spektrum bozukluğu. Daktylos Yayınları.

Kırcaali-İftar, G. (2012). Otizm spektrum bozukluğuna genel bakış. Tekin-İftar E. (Ed.), Otizm Spektrum Bozukluğu Olan Çocuklar ve Eğitimleri (s. 1744). Vize Yayınc1lık.

Kuder, J. (2015). Comparing video modeling to discrete trial teaching for teaching Daily living skills. [Unpublished Master's dissertation]. Rowan Üniversitesi, Department Of İnterdisciplinary And İnclusive Education.. ABD.

Lee, C. Y. O., Anderson, A. and Moore, D. W. (2014). Using video modeling to toilet train a child with autism. Journal of Developmental and Physical Disabilities, 26, 123-134. https://doi.10.1007/s10882-013-9348-y

McCoy, K. and Hermansen, E. (2007). Video modeling for individuals with autism: a review of model types and effects. Education and Treatment of Children, 30 (4), 183-213.

Mechling, L. (2005). The effects of instructor-created video programs to teach students with disabilities: a literature review. Journal of Special Education Technology, 20, 25-36. https://doi.org/10.1177/016264340502000203

Mechling, L. C., and O’Brien, E. (2010). Computerbased video instruction to teach students with intellectual disabilities to use public bus transportation. Education and Training in Autism and Developmental Disabilities, 45, 230-242. 
Nikopoulos, C., and Keenan, M. (2007). Using video modeling to teach complex social sequences to children with autism. Journal of Autism Developmental Disorders, 37, 678-693. https://doi.org/10.1007/s10803006-0195-x

Nikopoulos, K., and Keenan, M. (2003). Promoting social initiations in children with autism using video modeling. Behavioral Interventions, 18, 87-108. https://doi.org/10.1002/bin.129

Shipley-Benamou, R., Lutzker, J. R., and Taubman, M. (2002). Teaching daily living skills to children with autism through instructional video modeling. Journal of Positive Behavior Interventions, 4, 165-175. https://doi.org/10.1177/10983007020040030501

Spencer, L. G. (2002). Comparing the effectiveness of static pictures vs. video modeling on teaching requesting skills to elementary children with autism. [Unpublished Doctoral dissertation]. Georgia State University, Atlanta, A.B.D.

Tekin, E. and Kırcaali-İftar, G. (2001). Özel eğitimde yanlışsız öğretim yöntemleri. Nobel Yayın Dağıtım.

Tekin-İftar, E. ve Değirmenci, H. D. (2012). Otizm spektrum bozukluğu olan çocukların öğretimi. Tekin-İftar, E. (Ed.), Otizm spektrum bozukluğu olan çocuklar ve eğitimleri içinde (ss. 267-307). Vize Yayıncılık.

Tuncer, T. (2013). Görme yetersizliği olan çocuklar. Vuran, S. (Ed.), Özel ĕgitim. (s. 289- 321). Maya Yayıncilik

Varol, N. (2011). Beceri öğretimi ve öz bakım becerilerinin kazandırılması. Kök Yayınc1lık

Yavuz, M. (2019). Effectıveness of video prompting method in teaching cloth folding skill to individuals with autism spectrum disorders. European Journal of Special Education Research, 2(4),111,123. https://doi: 10.5281/zenodo.3229861

Yavuz, M. (2016). Otizm spektrum bozukluğu olan çocuklara ev içi becerilerin öğretiminde videoyla model olma ile videoyla ipucu yöntemlerinin etkililiğinin ve verimliliklerinin karşılaştırılması. [Yayımlanmamış doktora tezi]. Gazi Üniversitesi. 